\title{
Legal Opportunity Structures and Social Movements
}

\section{The Effects of Institutional Change on Costa Rican Politics}

Bruce M. Wilson

University of Central Florida

Juan Carlos Rodríguez Cordero

Universidad Estatal a Distancia

How does institutional change in established democracies affect the distribution of political power in society? The new constitutional court in Costa Rica allows the authors to analyze the effects of judicial reform on the capacity of politically marginalized groups to safeguard their constitutional rights. Particular attention is paid to homosexuals, AIDS patients, and labor unions. They argue that it was not the establishment of the court as such but rather the specific rules regulating access to and cost of approaching the court that enabled marginalized groups to push for their rights and effectively circumvent the traditional policy-making process. Although these groups did not win all their cases, they have nonetheless been able to achieve considerable success in the protection of their previously denied constitutional rights. The legal reform partially redistributed power in society from policy makers to social groups and individuals.

Keywords: legal opportunity; institutional change; constitutional court; marginalized groups; gays, people living with AIDS, Costa Rica

Authors' Note: This project was previously presented at the Universidad Estatal a Distancia, San José, Costa Rica, February, 2005. The authors would like to thank Kerstin Hamann and the anonymous reviewers at $C P S$ for their insightful comments on earlier versions of this article. 
$\mathrm{t}$ is, by now, conventional wisdom, that "institutions matter." Yet, it is not always clear
exactly how institutions matter. Even less is known about the distributional effects of institutional change. This is in part because changes in just one or two specific political institutions of any given country are rare and attributing the causal effects of altered outcomes to particular institutional origins is tricky. For example, during times of democratic transition, many different institutions -often spanning the political, economic, and social spheres- undergo simultaneous alterations of their institutional setup, which makes it difficult to disentangle the effects of just one of those institutional modifications. Here, we analyze a case that allows us to assess systematically the effects of the changes in one core governmental institution on the distribution of political power in society. When the constitutional chamber of the Costa Rican Supreme Court (Sala IV) was formed in 1989, all other key political and economic institutions remained constant. This scenario enables us to look at the effects of the creation of a new court on the strategies interest groups and minority groups have used in their quest to secure their constitutional rights. We argue that the new court's rules have, in fact, had profound consequences. First, the cost of access to the court was substantially reduced, which has altered the opportunity for access for groups that were previously marginalized from all aspects of Costa Rica's political process, including the judicial route. Second, this broadened access has been reflected in substantially altered policy outcomes.

The article unfolds as follows: section one lays out our argument in more detail. Section two briefly outlines Costa Rica's political institutions and policy process prior to the creation of the Sala $I V$. Section three examines the role the new court affords previously marginalized interest groups and individuals to use the legal opportunities (LO). Section four examines the use 
of the new legal opportunity by socially marginalized and politically weak individuals and groups. The conclusion sums up the argument and interprets our findings.

\section{Legislatures, Interest Groups, and Institutional Change}

Much of the literature on social movements has employed the notion of political opportunity structure to explain why social movements embrace particular strategies in their quest to influence policy decisions (for example, Hipsher, 1996; Imig \& Tarrow, 1999; Kitschelt, 1998; Marks \& McAdam, 1999; Tarrow, 1994). According to this argument, both stable and contingent factors outline specific opportunity structures (formally and informally) that social movements and interest groups can exploit when pursuing their goals. Once the political opportunity structure changes, it could be expected that the strategies embraced by movements and groups also change. Recently, the rejuvenation of national or supranational courts that many countries experienced (frequently as a result of democratization) has opened up a different type of opportunity structure, here labeled "legal opportunity" or LO (see Hilson, 2002). In many countries, courts have now emerged as active participants in the political process offering new opportunities to individual citizens, social movements, interest groups, and indeed, sitting politicians (Stone Sweet, 2002). However, outside of the US literature, the role of courts as political actors is still understudied. ${ }^{1}$

Where Supreme Courts have been created, reformed, or taken on a more activist role, citizens are often able to pursue governmental violations of their rights and to advance their

\footnotetext{
${ }^{1}$ Some exceptions are Hilson (2002); Stone Sweet (2002); Gibson and Caldeira (2003); Wilson \& Handberg (2000); Hammergren (1998).
} 
policy agenda through a new legal opportunity. ${ }^{2}$ Yet, the existence of a constitutional court does not automatically translate into success for citizens claiming their rights. According to Charles Epp (1998), it is not merely the existence of a LO coupled with activist judges that allows individuals and minority groups to pursue their rights agenda successfully. Instead, Epp (1998, p. 17) argues, "Combining rights consciousness with a bill of rights and a willing and able judiciary improves the outlook for a rights revolution, but material support for sustained pursuit of rights is still crucial." That is, in most cases, pursuing the legal option is often a lengthy and costly process that requires considerable resources on the part of the plaintiff in order to be successful since a rights revolution requires "widespread sustained litigation" (Epp 1998, p. 18). Evaluating the Costa Rican case, though, reveals that the resources required to file cases and to be successful are largely determined by the specific rules that regulate access to and the procedure of the court. Thus, if the new court required legal council, high filing fees, etc, Epp's observation would hold for the Costa Rican court. In that case, the creation of the constitutional court with its activist magistrates would allow only well-organized, well-financed groups to successfully pursue their agendas, a point that is also made in the social movements literature. As is evident from the cases presented here, though, poorly organized groups with no significant financial and organizational resources have successfully pursued their rights agenda through a LO in Costa Rica. We argue that this is the case because of the specific rules regulating the workings of the new court, and in particular the low access costs for filing cases and the opportunity to repeatedly file cases. The

${ }^{2}$ Examples of those courts can be found in several Latin American countries, the European Court of Justice, various European countries since the end of WWII, and courts in newly democratized countries, such as South Africa (Gibson \& Caldeira, 2003). 
resources necessary to pursue the legal path effectively are thus contingent on the rules that guide access to and the cost requirements of the court.

The question motivating this research is thus twofold. First, we assess how access to the new court is regulated in Costa Rica. Second, and related, we look at the consequences of broadened access to the new court and link the judicial reform to policy outcomes. We argue that the heightened access has led to a subtle, yet fundamental, redistribution of power in society and politics, resulting in a decentralization of policy-making power. To highlight the extent of that devolution of power we examine previously marginalized groups and individuals, who have found a new, low-cost legal opportunity to pursue governmental infringements on their rights and to influence the policy-making process. The court has thus granted them a new voice that provides them with an opportunity to participate in politics previously effectively foreclosed.

Costa Rica is a useful and illustrative case to study the effects on institutional change in the case of the new court. While Costa Rica's political institutions have been very stable since the promulgation of the 1949 Constitution, the creation of the constitutional Court in 1989 was the first major change in the country's core political institutions and was not accompanied by any other substantial institutional innovation or political or economic changes. Hence, it is possible to trace the effects of institutional change for the policy-making and implementation process and scrutinize the changing patterns of access for political actors both on the elite and mass level.

We are not concerned here with the motivations for the creation of the court (see Murillo, 1994; Wilson \& Handberg, 1999), nor with the impact on dominant interest groups, which have always had the opportunity to influence the policy process through established channels, such as political parties. Instead, we focus on how weak, marginalized actors have adjusted their behavior in response to the creation of a new institutional context and what the outcomes for politics are. 
That is not to suggest that established political actors did not also change their strategies or that there was no significant shift in the political power distribution among the branches of government. Indeed, many business groups have used the new LO and members of the Legislative Assembly quickly recognized and protested the limits on their powers presented by the new court. A leading PUSC (Partido Unidad Social Cristiana) deputy, Constantino Urcuyo, for example notes "the appearance of the Sala IV has put a brake on the abuse of power; it is natural that the abusers protest" (1995, p. 46). Here, though, we focus on groups that have traditionally had very limited access to policy-making structures in Costa Rica to illustrate the extent of the shift in influence on policy making.

\section{Policy-making Prior to Judicial Reform: Restricted Access for Marginalized Groups}

Prior to the reform of the Supreme Court, the policy-making process provided scant opportunities of access to marginalized groups or individuals. Studies of Costa Rican politics generally emphasize the importance of two major political parties, the social democratic Partido Liberación Nacional (National Liberation Party, PLN) and the center-right Partido Unidad Social Cristiana (Social Christian Unity Party, PUSC). ${ }^{3}$ They also point to the struggle for policymaking supremacy between the two popular branches of government: the 57-member Legislative Assembly and the executive branch (Booth, 1998; Carey, 1996). Most studies pay little or no

\footnotetext{
${ }^{3}$ We include the PUSC's precursor parties, which were generally called "la oposición" until the creation of PUSC in 1983.
} 
attention to the role of the Supreme Court. ${ }^{4}$ Before to the creation of a constitutional chamber within the Supreme Court in 1989, this analysis was both an appropriate and accurate rendition of the policy-making structure. Costa Rica has held free, open, and honest elections every four years since 1953. Two major political parties have controlled the presidency and the legislative assembly since that date. These parties routinely captured over 90 percent of the presidential vote and alternated control over the legislative assembly vote; third parties played only a minor role (Wilson, 1998, pp. 46-48). ${ }^{5}$ Minority interests thus remained underrepresented in the party system.

The Costa Rican presidency is one of the weakest in the hemisphere (Mainwaring \& Shugart 1997, p. 432) while political power is devolved among four branches of government: the executive, legislative assembly, Supreme Court, and a quasi-fourth branch, Tribunal Supremo de Elecciones (Supreme Tribunal of Elections, TSE). A prohibition on immediate re-election and then (after a 1969 amendment) a total prohibition on re-election further weakened the President's influence. ${ }^{6}$ While most policy-making power was vested in the legislative assembly, a bar on immediate reelection of deputies (diputados) diminished their ability to establish their institutional powers or create political bailiwicks. Since the end of the civil war, the powers of the popular branches have been further eroded by the expansion of existing and newly created autonomous institutions

${ }^{4}$ Much of the growing literature on the Supreme Court takes on a legalistic viewpoint (see for example the essays in Revista Parlamentaria 1995). Very little is written on the political and policy-making impact of the reformed court (Wilson, et al., 2004, Wilson, 1998; Wilson \& Handberg, 1999; Rodríguez Cordero, 2002a, 2002b; 2003).

5 A major shift in electoral politics began in 1998 with a significant rise in abstention rates and third parties' vote share (Wilson, 2003).

${ }^{6}$ In 2003 the Sala IV ruled the prohibition on presidential reelection unconstitutional (Resolution $\mathrm{N}^{\circ}$ 2003-02771). 
(Wilson, 1998). Socially marginalized or politically weak groups that lacked easy access to and representation by the two dominant political parties were thus effectively locked out of the policymaking process and their interests were seldom heard or defended.

\section{The Role of the Pre-Reformed Supreme Court}

Although the 1949 constitution formally established the Supreme Court as a co-equal power with the popular branches of government, it continued to play much the same minor role it had under the old constitution. The country's civil law tradition, as in the rest of Latin America, severely constrained Supreme Court magistrates' actions. Magistrates were highly deferential to popularly elected leaders for whom they believed the "power to legislate was absolute" (Urcuyo, 1995, p. 44). The popular branches consequently governed in the sure knowledge that the court would not declare their legislative acts unconstitutional and the Court acted only when laws were clearly against the "letter of the law" (Barker, 1991, pp. 362-63).

Various rules and norms further limited the Court's willingness or ability to take action against popular branches. A very restrictive definition of "standing" (the right to bring a case to court) was applied, which limited the number of cases that were brought to court. Compounding the situation was a rule requiring a super-majority (two thirds) vote of the Supreme Court's plenum to render a law unconstitutional (Murillo, 1994, p. 19). Supreme Court magistrates, as well as being schooled in the Civil Law tradition and its explicit nod to popular branch sovereignty, were also generally career judges, all of whom were necessarily inexperienced in constitutional issues before they were elected to the high court. Furthermore, all other challenges to state actions and omissions had to be appealed to the Jurisdicción Contencioso-Administrativa 
(Ortiz, 1990, p. 41), which was famously slow and inaccessible. This difficulty in declaring legislation and acts of the state unconstitutional fostered the Court's general deference to the political branches (Barker, 2000, p. 15). Before the creation of the Sala IV, the Costa Rican Supreme Court, like other Latin American courts, played a very minor role in the country's policy debates. Thus, no legal opportunity existed for individual citizens or interest groups to appeal the decisions of the government or to have their social and economic rights enforced. This is particularly relevant as the constitution itself grants individuals a wide range rights and liberties such as the right to life, movement, privacy, association, equality, etc (Constitution Title IV \& Title V).

Together with the restricted access to the court, its inactivity, timidity, and slow pace discouraged individuals and groups seeking the enforcement of their civil rights or the protection of their civil liberties from approaching the Court. Empirical evidence supports this assertion. A detailed examination of cases resolved by the pre-reformed Supreme Court shows that Gay individuals or groups filed no claims. ${ }^{7}$ This, though, might be explained by the relatively recent appearance of Gay groups as political actors in Costa Rica, but there were similarly few cases for other minority (or politically weak) groups; very few of those filed were successful. For example, there was just one case of constitutionality by a person injured at work, but it was rejected on April 13, 1965. Claims by workers, including the ones against the quasi-apartheid laws limiting people of color from working in certain parts of the country, were routinely rejected. A notable success by organized labor was in September 5, 1963 when a claim was filed by the Asociación Sindical de Profesores y Funcionarios Universitarios (Unionized Association of Professors and

\footnotetext{
${ }^{7}$ We use the term "Gay" broadly to include, gays, lesbians, and transgender people.
} 
University Employees), denouncing certain compulsory deductions on their salary. The court heard only three cases by foreign nationals demanding equal treatment before the law, all other claims were denied without a hearing. ${ }^{8}$ Prior to the creation of the Sala $I V$, minority parties, including the Communist Party (declared illegal after the civil war), failed to have any success at the Supreme Court. Thus, the paucity of cases filed with the pre-reformed Supreme Court reflects the lack of an effective Legal Opportunity available to interest groups or aggrieved individuals.

\section{Creating a Legal Opportunity}

In 1989, the Supreme Court was expanded through the addition of a seven-member constitutional chamber (Sala Constitucional or Sala IV); the first major revision of Costa Rica's political institutions since the promulgation of the 1949 constitution. The new court aggressively sought cases through major public education campaigns while simultaneously relaxing many of the previously rigid legal requirements to file a case. The evidence provided by the cases filed illustrates that marginalized groups and individuals can and do use the new court to pursue their rights without having to rely on the legislative process. This also means that the need to mobilize large numbers of affected people in collective action, for example in demonstrations or mass lobbying efforts, effectively disappears. The specific attributes and rules of the court facilitated a new legal opportunity for groups previously marginalized in the policy-making process. In particular, the regulations allowing for free and general access to the Court have meant that those groups and individuals that would otherwise be precluded from taking advantage of the country's

\footnotetext{
${ }^{8}$ Cases were resolved October 21, 1947; January 10, 1948; and on April 24, 1986 (Corte Suprema de Justicia-Sala Constitucional 2000).
} 
legal structures are now in a position to do so. These rules, together with the previously established political and financial independence of the judiciary (Wilson, et al., 2004), allows for political actors without privileged access to the legislative process to effectively pursue their rights and thereby downplays the importance of resources emphasized by Epp (1998).

Access to the Sala $I V$ is both easy and inexpensive. Litigants need no lawyers, no filing fees, no understanding of the legal nature of their claim; except for cases of unconstitutionality. Unlike the pre-reformed court, legal standing is now very broadly defined and allows any individual in the country to present a claim 24 hours a day and 365 days a year. Claims can be written in any language and on anything; it is the task of court employees to analyze and classify the cases by type. This process reduces the need for significant resources to pursue a judicial strategy. And, in a departure from the country's traditional reliance on Civil Code, the new court's rulings establish precedent that must be followed by all other courts and applied to all similar situations, which reduces the need for cases to be filed multiple times. As a direct consequence, the number of cases brought to the court increased exponentially; in the court's first full year of operation 2,296 cases were filed, which increased to more than 13,000 in 2003 producing a total caseload of over 114,000 (1989-2003). This rapid increase in caseload illustrates the recognition on the part of citizens that this new LO was an efficacious means through which to resolve disputes and affect policy. The appeal of the court as a LO was enhanced by the court's concerted effort to reduce the time to resolve cases; in 1994 average case duration was 9 months and 3 days, by 2002 it was just 2 months and 3 days (Proyecto Estado de la Nación en Desarrollo Humano Sostenible, 2003, p. 430). It is against this background that marginalized groups used the new legal opportunity. 


\section{The Use of the New Legal Opportunity by Gays and PLWA}

Prior to the creation of the Sala IV, gays and people living with AIDS (PLWA) had been strikingly unsuccessful in obtaining their rights. Gay rights and the rights of PLWA were either ignored at best or trampled on by government agents. Neither of the major political parties championed the agenda of either group and their inability to engage in collective action meant that other political opportunities were effectively closed to them.

While these two groups have some common interests, they have distinct emphases. Gayrights groups have generally sought legal "equality" with the rest of society and an end to discrimination, while PLWA groups are more concerned with access to anti-retroviral medications and the quality of medical and insurance coverage. These two groups are similarly disadvantaged in terms of pursuing their collective interests since many PLWAs and gay people do not wish to be publicly associated with these groups, due to a real fear of discrimination or stigmatization (R. Stern, interview, November 19, 1999). Consequently, Gays and PLWA in Costa Rica are poorly organized politically and unable to engage in effective collective action.

These difficulties were compounded by the short life and small membership of all AIDS and gay organizations in Costa Rica. The original gay and AIDS organizations sprang up in the 1980s and 1990s in response to police raids on gay and lesbian bars and in response to the AIDS crisis. But these groups invariably experienced short-lived existences. Currently, only the Centro de Investigación y Promoción para América Central de Derechos Humanos (Center for the Investigation and Promotion of Human Rights for Central America, CIPAC), founded in 1999, and the Asociación Agua Buena Prodefensa de los Derechos Humanos (Agua Buena Association for the Defense of Human Rights), founded in 1997, remain operational (Madrigal, 2002; Agua 
Buena, 2003). ${ }^{9}$ The ability of gays to organize and create associations to pursue their agenda was further hampered by the state's Registro Nacional, which refused to allow gay and lesbian associations to register their organizations and give them a legal presence until 1996 (ILGA, 1999).

The problems in the pursuit of their agendas were made worse by the social marginalization of gays and PLWA. Thus, an examination of the success or failure of these two groups' use of the new LO demonstrates the changes in Costa Rica's political landscape due to the creation and actions of the Sala IV.

\section{Gays}

According to Francisco Madrigal, president of the now defunct Costa Rican Gay rights organization Asociación Triángulo Rosa (Pink Triangle Association), homophobia is "deeply rooted in all Central American societies" resulting in discrimination and violence against gays (Espinoza, 1998). Madrigal's assertions are supported by Lind (1997), who documents the extent and consequences of Latin American homophobia including a general rise in violence against sexual minorities.

\footnotetext{
${ }^{9}$ These groups included the Asociación de Lucha Contra el SIDA (Association for the Struggle against AIDS), founded in 1996, which became Instituto Latinoamericano de Prevención y Educación en Salud; GAYPOA, which became the Asociación Triángulo Rosa (Pink Triangle Association). Both the Lesbian group Las Entendidas and the Movimiento 5 de abril ( $5^{\text {th }}$ of April Movement), Asociación por el Respeto a la Diversidad Sexual (Association for the Respect of Sexual Diversity) collapsed after short existences. According to Daniel Soto, a Costa Rican gay rights activist, all these groups had very small active memberships and were characterized by serious divisions rather than unity of action (D. Soto, interview, May 18, 2000). In 2003, Agua Buena still had "no stable funding source" (Agua Buena, 2003).
} 
Although homosexuality is legal in Costa Rica, gays are still subject to extensive social discrimination and anti-gay violence especially at the hands of Chapulines street gangs. ${ }^{10}$ Indeed, in a 1999 poll conducted by UNIMER, 83.4 percent of Costa Ricans interviewed stated that homosexuality was never justified. This was a higher negative score than people's views on the use of violence (82.8 percent) and abortion ( 80.4 percent), both of which are criminal activities in Costa Rica (UNIMER, 1999). This appraisal reflects a deeply held anti-gay sentiment in Costa Rica, which hampers their ability to muster popular support for their agenda or support from political parties. ${ }^{11}$ Political scientist Jacobo Schifter states that as a result of social discrimination, "most gays would rather resign" from their job than be publicly identified as being gay (Carstensen, 1992, p. 36). Indeed, according to Stern (1999, p. 3), "hundreds of gay people are fired each year when their employers discover their sexual identity." Gays fired from their jobs for being gay were rarely willing to challenge the decision for fear of being exposed as gay. Consequently, gay rights did not appear on the political radar before the creation of the Sala IV.

In 1997, when national newspapers reported three gay hotels were promoting prostitution and sex tourism, the Instituto Costarricense de Turismo (Costa Rican Institute of Tourism, ICT) declined to investigate the veracity of the claims and instead began to look into ways to close the hotels (ILGA, 1999). According to Schifter (2000), the police are generally unsympathetic to gay victims of crime and for police officers most gays are "perverts who have chosen to embark on a life of crime, the same way that burglars have learned to steal." And, as one police officer states,

10 These gangs appeared in the late 1980s and sought out gays to rob, assault, and sometimes murder (Schifter, 2000).

11 The 2002 election campaign was the first time that a candidate from a major party had addressed a public meeting of GLBT people, but Psychologist Richard Stern's (2000) assertion that the "national culture ... still condemns and vilifies" gays, remains true today. 
"Nobody is born with an inclination to steal. The same is true of drugs and homosexuality" (Schifter, 2000, p. 152). Until the late 1980s, San José police routinely harassed and arrested patrons of gay bars (Schifter, 1989). There was little state protection of gays' safety.

The major political parties, for their part, have traditionally kept their distance from nascent gay organizations and, when in government, have even permitted some state institutions to foster a hostile environment for gays, including open discrimination. For instance, in 1990, immigration authorities threatened to deport gays and lesbians arriving in the country for a conference (Carstensen, 1992, p. 36). The pervasiveness of anti-gay feelings has often been fermented and fostered by government officials and church leaders. Even in the late 1990s, President Miguel Ángel Rodríguez Echeverría (PUSC 1998-2002) advocated the cancellation of an international gay and lesbian festival that was to be held in Costa Rica. The Archbishop of San José, Román Arrieta Villalobos, echoed his sentiment by urging his congregation to block the festival by any legal means. The festival was cancelled. Weeks later, 300 villagers of Sardinal de Carrillo, Guanacaste, led by local priests and politicians, blockaded a road to prevent gay tourists from going to a resort hotel frequented by gays (La Nación, October 25, 1998). ${ }^{12}$

Gays have taken recourse to the legal avenue more frequently since the introduction of the Sala IV, even though they have not always been successful in their appeals to the Supreme Court (see Table One). In 1998, for example, the Asociación Triángulo Rosa sued Román Arrieta Villalobos, the Archbishop of San José, and President Rodríguez for statements they made in the

12 A similar response was elicited by a proposed lesbian conference in Costa Rica in 1987 when the Minister of Security vowed to deny all lesbians entry to the country (Schifter 2000:2). The Catholic Church remains highly influential in Costa Rica. For example, government plans to implement a sex education program were effectively blocked when the Church hierarchy rejected the government's sex education materials. 
national media against a proposed Costa Rican gay and lesbian festival. The Archbishop was found not guilty on the basis that he had spoken in accordance with the Catholic Church's doctrine on homosexuality. $^{13}$

\section{[Table One about here]}

The Sala IV has rejected many other gay rights cases usually due to a lack of evidence. For example, in 1993 when the Minister of Security Luis Fishman stated gays would not be allowed to serve in the policy force, a case was filed with the Sala IV. The court rejected the case (Resolution No. 1099-93) arguing the minister had only made a statement rather than implemented an administrative act. The Sala $I V$ noted that it would only accept cases against actual administrative acts (M. Castillo, interview, November 19, 1999). Similarly, in 1998, a case was filed against the Ministry of Education and a private school claiming a teacher was fired for being gay. This case was rejected, as were other similar cases, due to a lack of evidence that the teacher was dismissed specifically for being gay, rather than some other reason.

There have, though, been some notable successes that would not have been possible before the creation of the Sala IV. An important early success for gays was the ending of police harassment. In 1994, a gay bar owner filed a case with the Sala IV against the police for unlawful arrest and abuse of authority. The Sala IV ruled in favor of the bar owner and, in addition, mandated the police be trained in how to deal with gays and transvestites (Resolution No. 4732-94), which effectively put an end to the police raids and significantly curtailed the general harassment

\footnotetext{
${ }^{13}$ President Rodríguez enjoyed immunity by virtue of his office and thus could not be prosecuted.
} 
of gays. Since that ruling the court has indicated its unwillingness to accept cases by anti-gay groups or individuals who wish to use the Court to block lawful meetings. For example, it rejected a claim that a gay festival would infringe on the fundamental rights of the appellants (Resolution No. 3808-98).

Another significant early success was in 1995 when Abraxas, a small group created to fight discrimination against gays and PLWA, petitioned the Registro de Asociaciones to become the first openly gay association to receive legal recognition from the state. Their request was denied by the Registro. The group immediately approached the newly created Ombudsman's office (Defensor de los Habitantes) and threatened legal action at the Sala IV. The Registro backed down and allowed the group to register, which opened the door for all subsequent Gay groups to gain legal recognition.

More recently, the public debate concerning Gay rights was reopened and taken to a new level when an Alajuela city family judge refused a marriage license to Yashin Castrillo Fernández to marry his same-sex partner (Expediente No. 03-400952-292-FA). Castrillo Fernández immediately appealed the decision to the Sala IV (Expediente No. 03-008127-007-CO). In an August 2003 vote (9237-03), the Sala IV agreed to examine article 14 of the Código de Familia (Family Law) and to take the unusual step of holding public hearings on the issue of gay marriage before making a final ruling (Angulo, 2003).

The interesting point of these cases, though, is that gays, either individually or through nascent organizations, have frequently used the court to attempt to further their agenda. Contrary to Epp's (1998) expectations, then, it is possible for poorly organized, under-funded gay groups to win court protection for their constitutional rights through the LO. Even though not all cases have been successful, the low cost, open access, and rapid resolution of cases allows groups and 
individuals to quickly file another case directly with the constitutional court and without incurring large financial costs or the need to mobilize large numbers of supporters for collective action.

\section{People Living with AIDS (PLWA)}

The challenge to claim their rights is still more difficult for people living with AIDS (PLWA). Victims of AIDS are stigmatized and frequently considered unsympathetic sufferers for two related reasons. First, they carry a contagious fatal disease, which is often believed to be a consequence of "morally questionable" activities, such as sexual promiscuity, prostitution, or illegal drug use. Secondly, many PLWA belong to another socially marginalized and politically disorganized group, homosexuals. While AIDS is not a "gay disease," it is often mistakenly viewed as such. In Costa Rica, this view is furthered by the fact that an estimated 64 percent of people identified as HIV-positive are gay (Espinoza, 1998). Thus, the social and political marginalization of gays is compounded for PLWA, which in turn makes undertaking political action to defend their individual rights hugely difficult. According to one AIDS activist, Guillermo Murillo, organizing PLWA is difficult, "because once symptoms of AIDS appear, the focus of people's attention is usually in trying to survive and keeping the fact secret. The disease strikes such crippling blows to self-esteem and emotional stability of most its victims that they are almost psychologically unable to advocate for themselves" (Stern, 1998). Ignorance of and hostility toward PLWA was rife even in the medical community. For example, the laboratory director for the Hospital Calderón Guardia, a central social security hospital in San José, refused to conduct medical examinations of people known to be infected with AIDS (Jiménez, 1997). In 1997 the Sala IV 
accepted a writ of amparo by a PLWA and forced the hospital to treat AIDS patients the same way as any other patient (Resolution No. 3001-97).

One consequence of this hostility toward PLWA, then, is a great deal of pressure for them to keep their identities secret and not to join a protest group to pursue changes in public policy through official political channels because the social consequences, feared or real, are very high. In addition, the chances of finding a strategic ally promoting their interests in politics are thin. According to a Tico Times editorial (September 26, 1997), many AIDS patients refused to acknowledge publicly their medical condition as it "would push them into the spotlight. Given the choice of death or admitting they had AIDS, time and time again, they chose death." While the social costs of engaging in political activity are potentially high, any benefits from successful political activity would be public goods, available to all PLWA. These factors result in apparently insurmountable collective action problems.

A fundamental interest of all PLWA is the ability to gain access to anti-retroviral medications. From the earliest days of the AIDS crisis in the 1980s, PLWA were unable to receive these medications through the government-controlled health care system. Furthermore, they were denied care from government-owned hospital laboratories and received no protection from discrimination in employment or other areas. It was not until the 1990s that small, underfunded AIDS groups began to appeal to the Sala IV. The use of the new LO allowed this diverse and disparate group of individuals to overcome their collective action problems, their lack of resources, and their social and political marginalization to pursue substantial parts of their agendas. The need to create political support structures, change societal, or muster massive levels of resources was effectively removed. 
The creation of the Sala IV, though, did not automatically produce rulings in favor of PLWA's demands to gain access to appropriate medicine and an end to discrimination. Indeed, soon after the creation of the Sala IV, AIDS activist Jacobo Schifter filed a writ of amparo. Then, 18 months later in 1992, the Sala IV accepted the argument of the state's national health care agency Caja Costarricense del Seguro Social (CCSS) and ruled against the case (Resolution No. 280-92). The CCSS argued that the anti-AIDS drug, AZT, would not "cure" patients of AIDS, but would result only in a "prolonged course of deterioration" (Stern \& Matamoros 1999, p. 17).

In 1996, an American psychologist Richard Stern organized a small number of his clients, who were persons living with AIDS, into a "Patients' Coalition." This small group discussed alternative strategies to obtain the newest anti-retroviral drugs. With the 1992 failure of a judicial strategy, the group was hesitant to approach the Sala IV. Many of the members believed that a second loss at the Supreme Court would "close the door to future negotiations with the government" (Stern, 1999, p. 4; R. Stern \& G. Murillo Interviews November 19, 1999). For the first year the group negotiated with pharmaceutical companies for subsidized drugs and attempted a dialogue with the relevant government officials to pay for those drugs (Jiménez, 1997; Stern, 1998). The group failed to secure donated medicines from the pharmaceutical companies who argued, "we are an industry: we cannot fund this type of treatment" (Ávalos, 1997). But the group was also unsuccessful with its traditional lobbying efforts of government agencies. Stern (1999: 4) concludes that it "became apparent that the health care officials had no intention of providing [anti-AIDS] medications to anyone."

After a year without any success, a new group was formed with representatives of PLWA and representatives of various NGOs working on health issues in Costa Rica. In August 1997, the group sponsored a lawsuit, which was filed in the names of three PLWA. After filing the case, a 
fourth person was added to the writ, William García, a critically ill AIDS patient (Expediente No. 5778-V-97; M. Castillo, personal communication, March 11, 2000). García’s doctors provided documentation arguing that the drugs were his only possibility for survival, thus making the case one of "life or death." In the subsequent weeks the court's clerks and newspapers were "bombarded" with information concerning García's declining condition and impressing on the court the need for a speedy and favorable resolution. ${ }^{14}$ As in 1992, executive president of CCSS, Álvaro Salas, argued against the provision of anti-retroviral drugs noting their inability to cure the patients. Furthermore, he claimed issuing of the drugs would be "financially impossible" at an estimated cost of $\$ 800$ per month per patient (Tico Times, September 26, 1997: 12; Ávalos 1997).

Within three weeks of the filing of the case, the Sala IV ruled in favor of the provision of free, anti-retroviral drugs to all AIDS patients in Costa Rica (Resolution No. 5934-97). The constitutional basis of the court's decision lies in Article 21, which states "life is inviolable." The court reasoned, "What good are the rest of the rights and guarantees, the institutions and their programs, the advantages and benefits of our system of liberties, if a person cannot count on the right to life and health assured?" By the end of 1998, more than 400 AIDS patients gained free access to the anti-retroviral medicines (Stern, 1999, p. 4). ${ }^{15}$ Even though Costa Rica has a civil law legal tradition, cases that are decided by the Sala IV carry the weight of precedent; all other similar cases must follow the same legal reasoning as original case decision. Thus, the low costs of appealing to

14 M. Castillo, interview, November 19, 1999. This version of events was corroborated by Supreme Court Letrado (clerk) C. Hess, interview November 15, 1999.

${ }^{15}$ Although access was immediate for the four people named in the ruling, the CCSS was slow to extend the rule to all PLWA. Another 30 cases were filed before the precedent was acknowledged and access to the medicines became automatic. 
the Sala IV and the favorable decision precluded the need for other individuals to appear before the court and risk being publicly identified as HIV-positive.

Table Two illustrates the profound legal impact of the 1997 AIDS ruling. In response to the ruling, other groups of chronically ill people used the same strategy to have the state guarantee and pay for their medications. Within two years of the AIDS ruling, the Sala IV ruled in favor of the free provision of medications for 15 other chronic diseases including cancer, epilepsy, and multiple sclerosis (Ávalos \& Méndez, 1999). The court has since ruled in favor of free medications for two types of incurable sclerosis, which are even more costly than the treatment for AIDS. More recently, four liver disease patients won a court ruling, using the same legal argument as in the AIDS case, to require the CCSS to continue a liver transplant program (Resolution No. 7532-04; Ávalos, 2004). As in gay rights cases, the court is less supportive of PLWA's discrimination cases due to the difficulty of proving motivation.

\section{[Table Two about here]}

\section{Labor Unions}

Another historically marginalized group that has employed the new LO to force the state to recognize and uphold its existing constitutionally guaranteed rights is organized labor. After a brief period of significant political influence before the Civil War, unions were systematically and severely weakened. The largest unions sided with the losing side of the war and consequently, successive governments engineered legal rules to weaken unions' strength. The impact of these anti-union policies was particularly effective in the private sector, where union membership is 
very low (7 percent). While public sector unions enjoy higher membership levels (60 percent), various laws and decrees have curtailed their organizational powers (Wilson, 1998, pp. 69-70). Restrictions on union strength included a prohibition on strike actions by public unions and a refusal to protect union leaders from employers' reprisals. A major weakening of unions came from the broad interpretation of the 1943 Código de Trabajo (Labor Code) and its expansive definition of "public workers." The Labor Code, originally written to strengthen unions' political and economic power, removed the right to strike from more than 70 percent of the entire labor force (Villalobos, 1998). While the constitution guarantees the right to strike (Article $60 \& 61$ ), the Labor Code limits that right to non-public sector workers.

Since the creation of the Sala IV, labor unions have used the new LO in two different ways: first, to strengthen their organizational repertoire and regain the right to employ the strike option, and second, unions used the court's new power of constitutional review to challenge economic policies that might harm their members' interests.

Unions had a long history of lobbying governments to revise the Labor Code. Their strategy included eliciting international pressure from the International Labour Organisation (ILO) and the AFL-CIO. Yet, after fifty years of futile political pressure to change the Labor Code, four public sector unions jointly filed a case of unconstitutionality with the Sala IV. Eventually, the Sala IV accepted the unions' arguments and declared unconstitutional articles 376 a, b, e, and article 389 paragraph 2 of the Labor Code (Resolution No. 1317-98). As a result, the vast majority of workers regained their right to strike in support of their goals (Villalobos, 1998).

A second use of the new LO by organized labor has been to block, delay, or reverse unfavorable government policies by challenging them at the Sala IV. A pertinent example is the case of the privatization of cellular phone service. In 1987, a U.S. company was granted the right to 
supply cellular phone service in Costa Rica. Public sector unions, representing phone workers, feared this was the first step toward privatizing the whole telephone industry and would result in job losses and poorer working conditions. In 1993, the Sala IV resolved the issue in ruling the contracts unconstitutional. Cellular phones were deemed a type of telephone service, which, as the unions had argued, was a constitutionally mandated monopoly granted to the state phone company, ICE.

\section{Other groups and individuals}

Another weakly organized and socially marginalized group that has also successfully employed the new LO is prisoners. Prison overcrowding has been an ongoing problem for several years, but politicians generally ignored the issue. In 1996, the Sala IV accepted a case filed by a prisoner, Marvin Guevara Cerrera, and gave the La Reforma prison one year to provide minimally acceptable conditions for prisoners (Resolution No. 4576-96). The prison made an effort to address the problem, but a 1999 United Nations agency inspection found the jail was 139 percent above its intended capacity. In August 2000, the Sala IV revisited the issue of jail overcrowding and ruled that no more prisoners were to be set to the San Sebastián jail until minimum UN requirements for the treatment of prisoners were met (Resolution No. 7484-00). In response to this ruling the government funded the development of five new prison facilities and the renovation of several others (U.S. Department of State 2001).

Other cases highlight the lack of attention the Legislative Assembly paid to the Supreme Court in general and individual constitutional rights in particular prior to the existence of the Sala IV. For example, in 1985, a Costa Rican court convicted a journalist for practicing journalism without a license. Since there was no realistic political or legal option within Costa Rica, he appealed his 
case to the Inter-American Court of Human Rights. That international court ruled that Article 13 of the American Human Rights Convention (to which Costa Rica is a signatory) declares an individual's right to free speech and thus to freely practice journalism. However, the Costa Rican government viewed the ruling as advisory and not binding. It took another ten years and the creation of the Sala $I V$ before the journalist won his case and mandatory licensing of journalists was declared unconstitutional (Resolution No. 2313-95). Subsequently, the Sala IV made it explicit that it expected the Costa Rican government to live up to its international treaty obligations. This was powerfully illustrated in early 2003 when the Sala IV rejected the Pacheco (PUSC 2002-) government's attempt to reduce education expenditures by reducing the school year. The Sala IV declared the administration's decision to cut 27 days form the school year was unconstitutional. It argued the administration must comply with all international agreements signed by current or previous Costa Rican governments including the Convenio Centroamericano sobre la Unificación de la Educación Básica, which promised a minimum of 200 days in the academic year for Costa Rican students (Resolution No. 11515-02).

Another illustrative example of the open, low cost access to the Sala IV comes from a 10 year-old boy, Oscar Felipe Baltodano Valverde, who was routinely late for school due to the tardiness of the school bus that served his poor neighborhood. His writ of amparo was handwritten and filed without legal council. It claimed the bus company was impinging on his constitutional right to a free education. Although the court rejected this particular case, the bus company responded positively to his claim. Over the next eight years, Oscar Felipe filed over 140 cases, winning some and losing others. Although he has no legal training and no resources, he now acts as an unpaid legal defender for his poor neighborhood. He is facilitating the use of an effective LO that allows marginalized individuals to bypass the traditional political solutions and 
instead seek solutions from the Court (interview, Baltodano, July 6, 2004; Mastroeni, 1999; Mora, 2000).

Prior to the creation of the Sala $I V$, none of these classes of individuals or groups (journalists, school children, labor unions, or poor, marginalized people) were in a position to protect their constitutional rights effectively. But with the opening of a LO through the Sala IV, they could challenge the decisions of the popular branches, government agencies, and other individuals and efficiently pursue their agenda without the need to mobilize vast resources or organize collective actions.

\section{Implications of the cases: new legal opportunities and political outcomes}

How can we explain that marginalized groups in Costa Rica have been able to fight successfully for their constitutional rights when, in some cases, they had tried to do so for decades without success? An obvious answer is the creation of the new constitutional court. Yet, according to existing literature, new courts can only be used effectively if those pushing for their rights have substantial resources to engage in the legal access. Contrary to this expectation, in the Costa Rican case, many of the groups and individuals that have used the new court are poorly organized and often cannot marshal significant resources. The answer, then, has to be found in the particular rules guiding access to the court. Whereas previous studies have concentrated on cases where substantial resources were indeed necessary to use the courts, the Costa Rican court removes these barriers and is effectively open to all citizens regardless of their resources.

Enforcing rights was also possible because similar to many Latin American constitutions, Costa Rica's 1949 constitution contains an extensive list of individual and social rights and 
guarantees (Title IV \& Title V). Thus, the protection of the rights that homosexuals, PLWA, and other minority groups were seeking was already implicitly, if not explicitly, enumerated in the constitution. Yet prior to the creation of the court, no readily available option was available to any group, especially not poorly organized, socially marginalized ones to claim these rights. Assessing the strategy and success or failure of these groups answers the fundamental question of how highly marginalized groups managed to assert their rights in a society that did not recognize their rights. And, in the case of PLWA, it shows how such a group managed to force the state to use a significant part of its declining budget to pay for expensive anti-retroviral drugs to treat them, effectively making them a public good available to all PLWA even though only four people took the case to the court.

The new rules allowing for open access by individuals and groups previously marginalized from representing their interests in the political arena have had a profound impact on Costa Rican politics and society. In particular, new groups and individuals have now increased their political presence and power and are better able to defend their constitutionally granted rights. Other less atomized and socially marginalized groups can be expected to also be successful. In essence, interest groups, social movements, and also individuals can pursue a new, low-cost strategy that fundamentally alters Costa Rica's political dynamics.

Table Three contains a partial list of cases filed by weakly organized groups, broken down by appellant, that have been taken to the Sala IV. Clearly, various minority groups have taken advantage of the LO afforded by the Sala IV to pursue their agendas. While the list shows that not all cases were successful, it also hints at the relatively low cost and ease of following such a legal strategy. If a case fails, it is possible to file another similar case shortly afterwards without having to pay lawyers' fees, filing fees, or have any profound legal understanding of the law that is being 
challenged. But if the case is successful, the precedent allows all groups and individuals in similar positions to benefit from the ruling.

\section{[Table Three about here]}

The preceding analysis has demonstrated how the establishment of a constitutional court, the Sala IV, in Costa Rica, has exerted a profound impact on the country's policy-making process. Previously marginalized groups as well as individuals have gained cheap and effective access to the court, thus being able to ensure their rights vis-à-vis the government. This process has had farreaching implications. Most evidently, the policy-making autonomy that the government had enjoyed since 1949 has been severely curtailed as its policies are now subjected to the court's interpretation of their constitutionality. On a different level, though, the distribution of power in Costa Rica has been profoundly altered. Social movements and interest groups have been empowered, filtering power to some strata of society that oftentimes were politically marginalized prior to the creation of the Sala IV. In effect, the political system in Costa Rica has become more open through the establishment of a new court with respect to the protection of minority rights. The existence of the new legal opportunity means that as a strategy, the development of an extensive lobbying system might be less important and necessary since groups and individuals can now claim their rights without recourse to the legislative path. Finally, it can be observed that the strategies and behaviors of political actors both on the elite and mass level have adjusted to the changing institutions, in particular the new legal opportunity. While other strategies, such as collective action, are still being used, their relevance has been reduced in some cases, which has 
benefited particularly those social groups for which collective action presented a sizable problem, such as gays, PLWA, or prisoners' rights groups.

More generally, the way in which marginalized groups in Costa Rica have approached and relied on a new legal opportunity to pursue their agendas may also throw light on the behavior of similar groups in other countries. In the case of PLWA, for example, the model used in Costa Rica has been consciously replicated in other Central American countries including El Salvador, Honduras, and Panama. In Panama PROBSIDA (Foundation for the Well-being and Dignity of People with AIDS) used a two-pronged strategy negotiating with the relevant state health care agencies and threatening to file a case with the Supreme Court (Stern, 1998). Similar strategies have also been pursued in a variety of other countries including the UK (using the European Court of Justice) and in South Africa (BBC, 2002) through the Supreme Court to force the government to fund Aids treatment. ${ }^{16}$ All these cases provide ample material to further investigate the effects of institutional change-in particular, reform of the judicial system-on political behavior and distribution of power in democratic societies.

\footnotetext{
${ }^{16}$ For the use of legal opportunities in other countries, including the United States, see Sanders (1996), Wilets (1994), or Epp (1998), for example.
} 


\section{References}

Agua Buena. (2003). Asociación Agua Buena Prodefensa de los Derechos Humanos: Historia [Agua Buena Association for the Defense of Human Rights]. Retrieved from http:/www.aguabuena.org/historia.html

Angulo, J. (2003). Sala IV acoge para estudio unión entre personas del mismo sexo [Constitucional chamber agrees to examine same-sex marriage unions]. Gay Costa Rica. Retrieved from http://www.costaricagay.com/htmls/uniongay.html

Ávalos, A. (1997, April 16). CCSS no da Fármacos: 300 enfermos de sida carecen de medicinas [CCSS does not provide prescriptions: 300 AIDS patients without medicines]. La Nación. Retrieved from http://www.nacion.com/ln_ee/1997/abril/16/sida.html

Ávalos, A. (2004, July 7). CCSS obligada a reactivar el plan de transplantes de hígado [CCSS must restart the liver transplant program]. La Nación, p. 5A.

Ávalos, A., \& W. Méndez. (1999, November 29). Caja y Sala IV chocan por medicinas [CCSS and constitucional chamber clash on medicines]. La Nación. Retrieved from http://www.nacion.com/ln_ee/1999/noviembre/29/pais1.html

Barker, R. S. (1991). Taking Constitutionalism Seriously: Costa Rica's Sala Cuarta. Florida Journal of International Law, 6, 349-397.

Barker, R. S. (2000, March). Judicial Review in Costa Rica: Evolution and Recent Developments. Paper presented at Latin American Studies Association, Miami, FL.

Booth, J. A. (1998). Costa Rica: Quest for Democracy. Boulder, CO: Westview.

British Broadcasting Corporation (2002, March 25). SA Courts Back Anti-HIV drug. Retrieved from http://news.bbc.co.uk/2/hi/africa/1893449.stm.

Carey, J. M. (1996). Term Limits and Legislative Representation. Cambridge, UK: Cambridge University Press. 
Carstensen, J. (1992). Fighting fear in Costa Rica. The Advocate, 595, 36-38.

Constitución Política de la República de Costa Rica. (1998). San José, Costa Rica: Editorial Juricentro.

Corte Suprema de Justicia-Sala Constitucional. (2000). Jurisprudencia constitucional: recopilación de las sentencias de constitucionalidad dictadas entre 1890 y 1990 por la Corte de Casación y la Corte Plena [Constitucional precedents: Abridgement of the constitucional sentences between 1890 and 1990 by the Cassation Court and the Plenary Supreme Court]. San José, Costa Rica: Editorial UNED.

Corte Suprema de Justicia-Sala Constitucional. (2004). Base de Datos del Centro de Documentación de la Corte Suprema de Justicia [Database, Information Center of the Supreme Court of Justice]. San José, Costa Rica: Corte Suprema de Justicia.

Editorial. (1997, September 27), Tico Times, p. 12.

Epp, C. R. (1998). The Rights Revolution: Lawyers, Activists, and Supreme Courts in Comparative Perspective. Chicago, University of Chicago Press.

Espinoza, M. (1998, December 11). Central American Gays Blast Violence, Laws. Tico Times. Retrieved from http://www.ticotimes.net/archive//12_11_98_2.htm

Gibson, J. L., \& Caldeira, G. (2003). Defenders of Democracy? Legitimacy, Popular Acceptance, and the South African Constitutional Court. Journal of Politics, 65, 1-30.

Hammergren, L. A. (1998). The politics of justice and justice reform in Latin America. Boulder, CO: Westview.

Hilson, C. (2002). New social movements: The role of legal opportunity. Journal of European Public Policy, 9, 238-255. 
Hipsher, P. L. (1996). Democratization and the decline of urban social movements in Chile and Spain. Comparative Politics, 28, 273-298.

Imig, D., \& Tarrow, S. (1999). The Europeanization of movements? A new approach to transnational contention. In D. della Porta, H. Kriesi \& D. Rucht. (Eds.), Social movements in a globalizing world. New York: St. Martin's.

International Lesbian and Gay Association. 1999. World legal survey: Costa Rica. Retrieved from http://www.ilga.org/Information/legal_survey/americas/costa_rica.htm

Jiménez, Y. L. (1997, June 1). ¡No nos dejen morir! [Don’t let us die!]. La Nación. Retrieved from http://www.nacion.com/dominical/1997/junio/01

Kitschelt, H. (1986). Political opportunity structures and political protest: Anti-nuclear movements in four democracies. British Journal of Political Science, 16, 57-85.

Ley de la Jurisdicción Constitucional. (1989, octubre 19). Ley No. 7.135 de 11 de octubre de 1989. La Gaceta, No. 198. San José, Costa Rica.

Lind, A. (1997). Out of the closet and into la calle." NACLA [North American Congress on Latin America], 30, 6-10.

Madrigal, F. (2002). Los gays y las lesbianas en Costa Rica [Gays and lesbians in Costa Rica]. Centro de Investigación y Promoción para América Central de Derechos Humanos (CIPAC). Retrieved from http://www.cipacdh.org/azul/glbtcr.html

Mainwaring, S., \& Shugart, M. S. (Eds.). (1997). Presidentialism and democracy in Latin America. New York: Cambridge University Press.

Marks, G., \& McAdam, D. (1999). On the relationship of political opportunities to the form of collective action: The case of the European Union. In D. della Porta, H. Kriesi and D. Rucht. (Eds.). Social movements in a globalizing world (pp. 97-111). New York: St. Martin's. 
Mastroeni, L. R. (1999, February 5). Defensor de su barrio [Defender of his neighborhood]. Al Día, p. 8.

Mora, E. (2000, February 14). Niño ganó disputa a Ministro [Child wins dispute with minister]. La Nación, p 18 A.

Murillo V., J. (1994). La Sala Constitucional: Una revolución político-jurídica en Costa Rica [The constitutional chamber: A politico-juridical revolution in Costa Rica]. San José, Costa Rica: Editorial Guayacán.

Ortiz O., E. (1990). El control de constitucionalidad en Costa Rica. [The constitutionality control in Costa Rica]. Revista de Ciencias Jurídicas, 66, 17-49.

Proyecto Estado de la Nación en Desarrollo Humano Sostenible (2003). IX Informe Estado de la Nación 2002 [Ninth report on the state of the nation]. San José, Costa Rica: Proyecto Estado de la Nación en Desarrollo Humano Sostenible-Consejo Nacional de Rectores. Revista Parlamentaria. (1995). Sala Constitucional ¿Defensora de la Constitución u obstáculo para el desarrollo? [Constitutional chamber: Defender of the constitution or an obstacle to development? Special issue], 3 .

Rodríguez Cordero, J. C. (2002a). Entre Curules \& Estrados: la consulta preceptiva de las reformas constitucionales en Costa Rica [Between Curules \& Courts: The mandatory consultation of constitutional amendments in Costa Rica], San José, Costa Rica: Investigaciones Jurídicas.

Rodríguez Cordero, J. C. (2002b). (Re)equilibrios políticos en Costa Rica: El poder constituyente y el control de constitucionalidad [Political (re)equilibria in Costa Rica: The constituent power and the constitutionality control]. South Eastern Latin Americanist, 45, 15-28.

Rodríguez Cordero, J. C. (2003, October). Sala Constitucional y equilibrio de Poderes [Constitutional chamber and powers equilibrium]. IX Informe Estado de la Nación 2002. San José, Costa Rica: Proyecto Estado de la Nación en Desarrollo Humano Sostenible-Consejo Nacional de Rectores. 
Sanders, D. (1996). Getting Gay and Lesbian issues on the International Human Rights Agenda. Human Rights Quarterly, 18, 67-106.

Schifter, J. (1989). La formación de una contracultura: Homosexualismo y SIDA en Costa Rica [The formation of a counterculture: Homosexuality and AIDS in Costa Rica]. San José, Costa Rica: Guayacán.

Schifter, J. (2000). Public Sex in Latin Society. Binghamton, NY: Haworth/Latino Press.

Stern, R. (1999). Costa Rican AIDS patient coalition wins drug "cocktail” in high court ruling. Psychology International, 10, 3-4.

Stern, R. (1998, September 30). Lobbying Vital for AIDS Treatment-The Lesson from Central America. Panos. Retrieved from http://www.oneworld.org/panos/news/30sept98.htm

Stern, R. \& Matamoros, A. (1999). Activists win supreme court challenge in Costa Rica. HIV/AIDS and Human Rights: Stories from the Frontlines. Prepared by the International Council of AIDS Service Organizations, 17-19. Retrieved January 23, 2004, from http://www.icaso.org/icaso/docs/stories_english.pdf

Stone Sweet, A. (2002). Constitutional courts and parliamentary democracy. West European Politics, 25, $77-93$.

Tarrow, S. (1994). Power in movement: Social movements, collective action, and politics. Cambridge, UK: Cambridge University Press.

UNIMER. (1999). Encuesta [Opinión poll] Retrieved from: http://www.nacion.co.cr/ln_ee/encuestas/unimer/grafico21.gif U.S. Department of State. (2001, February). Country Reports on human rights practices: Costa Rica. Released by the Bureau of Democracy, Human Rights, and Labor. Retrieved June 6, 2001, from http://www.state.gov/g/drl/rls/hrrpt/2000/what/746.htm

Urcuyo, C. (1995). La Sala IV: Necesarios límites al poder [The Sala IV: Necessary limits to power]. Revista Parlamentaria, 3, 37-48. 
Vega, L. A. (1998, October 25). Desarman bloqueo por grupo de gays [Roadblock removed for gay group]. La Nación. Retrieved from http://www.nacion.com/ln_ee/1998/october/25/pais9.html

Villalobos, C. A. (1998, March 4). Sala IV modifica artículos del Código de Trabajo: Amplían derecho a huelga [Sala IV modifies labor code: The right to strike gets wider]. La Nación. Retrieved from http://www.nacion.com/ln_ee/1998/marzo/04/pais1.html

Wilets, J. D. (1994). International human rights law and sexual orientation. Hastings International and Comparative Law Review, 18, 1-120.

Wilson, B. M. (1998). Costa Rica: Politics, economics, and democracy. Boulder, CO: Lynne Rienner.

Wilson, B. M. (2003). The Costa Rican general election of 3 February 2002 and the second round presidential election, 7 April 2002. Electoral Studies, 22, 509-516.

Wilson, B. M. \& Handberg, R. (1999). From judicial passivity to judicial activism: Explaining the change within Costa Rica's supreme court. NAFTA: Law and Business Review of the Americas, 4, 522-543.

Wilson, B. M. \& Handberg, R. (2000). Costa Rica's new constitutional court: A loose political cannon? South Eastern Latin Americanist, 43, 58-79.

Wilson, B. M., Rodríguez Cordero, J. C., \& Handberg, R. (2004). The best laid schemes... gang aft agley: Judicial reform in Latin America - Evidence from Costa Rica. Journal of Latin American Studies, 36, 507-531. 
Bruce M. Wilson (Ph.D., Washington University) is associate professor of political science at the University of Central Florida. He is author of Costa Rica: Politics, Economics, and Democracy and numerous articles on political economy and judicial reform in Latin America. His research has appeared in the Journal of Latin American Studies, Comparative Politics, and Comparative Political Studies. He is the Editor of The Latin Americanist.

Juan Carlos Rodríguez Cordero is a practicing attorney at law and professor at the Graduate Studies System, Universidad Estatal a Distancia, in Costa Rica. He received his degrees in law and in political science from the University of Costa Rica. He has authored numerous books and articles on legal and judicial reform issues. His recent articles have appeared in the Journal of Latin American Studies, Revista Parlamentaria, and South Eastern Latin Americanist. 


\section{TABLES}

Table 1: Selected cases involving gay rights

\begin{tabular}{|c|l|c|}
\hline Ruling No. $^{\text {a }}$ & \multicolumn{1}{|c|}{ Argued in the Case } & Outcome \\
\hline $1099-93$ & Against public anti-gay declarations of the Minister of Security & Lost \\
\hline $4732-94$ & Police brutality at a gay discotheque & Won \\
\hline $1942-97$ & Anti-gay policies at "La Reforma" jail & Lost \\
\hline $3808-98$ & Right to have a Gay festival in Costa Rica & Won \\
\hline $4016-98$ & Student expelled from school for being gay & Lost \\
\hline $9237-03$ & Agreed to examine the Family Law concerning same sex marriage & Won \\
\hline
\end{tabular}

Source: Corte Suprema de Justicia-Sala Constitucional. 2004.

a. Case's resolution number; the two numerals after the hyphen signify the year of the decision.

Table 2: Selected PLWA and other related cases

\begin{tabular}{|r|l|c|}
\hline Ruling No. & \multicolumn{1}{|c|}{ Argued in the Case } & Outcome \\
\hline $280-92$ & Access to medical treatment for people with AIDS & Lost \\
\hline $5934-97$ & Access to medical treatment for people with AIDS & Won \\
\hline $3001-97$ & Calderón Guardia Hospital refused lab tests for people with AIDS & Won \\
\hline $3024-98$ & Job discrimination against person with multiple sclerosis & Lost \\
\hline $5788-98$ & Right to die without pain & Won \\
\hline $4119-00$ & Against CCSS (social security agency) fired worker for having AIDS & Lost \\
\hline $9737-00$ & Worker fired for having multiple sclerosis & Won \\
\hline $1432-03$ & Right for a Medical Doctor to work in a latex-free environment & Won \\
\hline $7532-04$ & CCSS shall continue the Liver's Transplant Program for Adult Patients & Won \\
\hline
\end{tabular}

Source: Corte Suprema de Justicia-Sala Constitucional. 2004.

a. Case's resolution number; the two numerals after the hyphen signify the year of the decision.

Table 3: Major Cases Filed with the Sala IV by Minorities, Marginalized Groups, and Individuals

\begin{tabular}{|r|l|c|}
\hline Ruling No. $^{\mathrm{a}}$ & \multicolumn{1}{|c|}{ Argued in the Case } & Outcome \\
\hline & Accommodating disabled people & \\
\hline $567-90$ & No Braille exams for blind people the Civil Service evaluations. & Won \\
\hline $6732-98$ & Television networks did not translate programs into sign Language. & Won \\
\hline $5792-01$ & Newscasts lack translation into sign language. & Won \\
\hline $8450-00$ & Schools lack oral tests for the blind. & Lost (c) \\
\hline $10826-00$ & $\begin{array}{l}\text { Academic modification to indicate a student's "special needs" was } \\
\text { marked on the Diploma. }\end{array}$ & Won \\
\hline $8559-01$ & Taxi drivers refuse to transport blind people with guide dogs. & Won \\
\hline
\end{tabular}


Table 3 (continued)

\begin{tabular}{|c|c|c|}
\hline $11050-01$ & $\begin{array}{l}\text { Handicapped are not permitted to enroll in courses from the Sports } \\
\text { Coliseum at Heredia. }\end{array}$ & Lost (c) \\
\hline & Access for disabled people & \\
\hline $4543-99$ & $\begin{array}{l}\text { CCSS (social security agency) lacks adequate facilities for } \\
\text { handicapped people. }\end{array}$ & Won \\
\hline $235-00$ & $\begin{array}{l}\text { Public fences along sidewalks of San José cause problems for } \\
\text { handicapped people. }\end{array}$ & Won \\
\hline $2305-00$ & $\begin{array}{l}\text { Judicial Branch Buildings lack secure access for Handicapped } \\
\text { people. }\end{array}$ & Won \\
\hline $2494-00$ & $\begin{array}{l}\text { Installation of public fences on San José sidewalks; causes serious } \\
\text { problems for blind people. }\end{array}$ & Lost (c) \\
\hline $7085-00$ & $\begin{array}{l}\text { IMAS (social assistance state agency) lacks appropriate installations } \\
\text { for handicapped people. }\end{array}$ & Won \\
\hline $8422-00$ & $\begin{array}{l}\text { Educational Institutions lacks appropriate installations for the } \\
\text { handicapped. }\end{array}$ & Won \\
\hline $1820-99$ & Lack of wheelchair access to Judicial Branch Buildings. & Lost (c) \\
\hline $2197-99$ & INS (state insurance agency) lacks facilities for handicapped people. & Lost (c) \\
\hline $3430-99$ & $\begin{array}{l}\text { MCJD (Ministry of Culture, Youth and Sports) lacks adequate } \\
\text { facilities for handicapped people. }\end{array}$ & Lost (c) \\
\hline $8386-99$ & $\begin{array}{l}\text { BNCR (state bank) lacks facilities for handicapped to sign with a } \\
\text { digital fingerprint. }\end{array}$ & Lost (c) \\
\hline $12062-01$ & $\begin{array}{l}\text { Judicial Branch failed to respect the Law of Handicapped for } \\
\text { Designations. }\end{array}$ & Lost (c) \\
\hline $107-01$ & Entry turnstiles on buses prevent handicapped from using the buses. & Lost (c) \\
\hline \multirow[t]{2}{*}{$12062-01$} & $\begin{array}{l}\text { Judicial Branch failed to respect the Law of Handicapped for } \\
\text { Designations. }\end{array}$ & Lost (c) \\
\hline & Job discrimination against disabled people & \\
\hline $10637-00$ & $\begin{array}{l}\text { A taxi concession was denied for being blind and to his/her mother } \\
\text { for being older than } 60 \text { years. }\end{array}$ & Lost $(\mathrm{d})$ \\
\hline $2432-01$ & Lost police job for being handicapped. & Lost (d) \\
\hline \multirow[t]{2}{*}{$8551-98$} & Blind woman was not considered for a job because of disability. & Lost (c) \\
\hline & Freedom of Religion & \\
\hline $172-89$ & $\begin{array}{l}\text { Protestant church was arbitrarily banned for excessive noise and } \\
\text { annoyances. }\end{array}$ & Won \\
\hline $590-91$ & Preference for evangelical students at a Methodist School. & Won \\
\hline 3914-99 & Against an image of Virgin Mary in school; appellant not catholic. & Won \\
\hline $8387-99$ & Against an image of Virgin Mary in school; appellant not catholic. & Won \\
\hline $787-00$ & $\begin{array}{l}\text { Rights granted to Catholic priests serving jails were denied at jail to } \\
\text { Evangelical priest }\end{array}$ & Lost $(\mathrm{d})$ \\
\hline $2286-00$ & Individual prohibited from preaching at a marketplace. & Won \\
\hline 9346-00 & $\begin{array}{l}\text { San José Municipality prohibits religious demonstrations in public } \\
\text { places. }\end{array}$ & Lost (c) \\
\hline
\end{tabular}




\begin{tabular}{|c|c|c|}
\hline 10916-00 & San José Municipality prohibits preachers in public places. & Lost (c) \\
\hline 797-01 & $\begin{array}{l}\text { JAPDEVA (Atlantic zone ports state agency) for contributions to the } \\
\text { Catholic Church. }\end{array}$ & Lost (e) \\
\hline $1866-01$ & $\begin{array}{l}\text { Tibás Municipality denied a permit for a Christian Congregation to } \\
\text { have an activity at the park. }\end{array}$ & Won \\
\hline $6428-01$ & $\begin{array}{l}\text { Rastafarians banned from "Oficentro La Sabana” (an office } \\
\text { complex) }\end{array}$ & Won \\
\hline \multirow[t]{2}{*}{$2640-01$} & $\begin{array}{l}\text { Health permissions are requested from Christian Congregations, } \\
\text { while not to Catholic centers. }\end{array}$ & Lost (c) \\
\hline & Ethnic Minorities & \\
\hline $1786-93$ & Identity meetings denied to indigenous people. & Won \\
\hline 2039-93 & Public Registry not inscribes or accepts Oriental documents. & Lost (e) \\
\hline $6097-93$ & Labor discrimination against Black worker. & Lost (c) \\
\hline $2242-94$ & Fired by municipal government for political belief and race. & Lost (c) \\
\hline $3204-95$ & Discriminated against Black model. & Lost (c) \\
\hline $3220-95$ & Political Parties against Blacks. & Lost (e) \\
\hline $509-96$ & $\begin{array}{l}\text { Against the required reading of a book with discriminatory content } \\
\text { against Blacks. }\end{array}$ & Lost (c) \\
\hline $966-98$ & Entrance to a private bar denied to Black patron. & Lost (c) \\
\hline $5813-00$ & Discrimination against Black soccer player. & Lost (c) \\
\hline \multirow[t]{2}{*}{$5445-01$} & Publicity barred for discrimination against Blacks. & Won \\
\hline & Women and gender discrimination & \\
\hline $2196-92$ & Husband's consent required for a woman's sterilization. & Won \\
\hline $3435-92$ & Equal rights for naturalization through marriage for Men and women & Won \\
\hline $3444-92$ & Discrimination against female athletes. & Lost (e) \\
\hline $629-94$ & $\begin{array}{l}\text { CCSS (social security agency) males refused social security benefits } \\
\text { from family or wife }\end{array}$ & Won \\
\hline $2648-94$ & $\begin{array}{l}\text { CCSS pays no benefits to men in common law marriages, if woman } \\
\text { works. }\end{array}$ & Won \\
\hline $5311-96$ & $\begin{array}{l}\text { Domestic violence law language that reads "man" should also be } \\
\text { understood as "woman." }\end{array}$ & Lost (e) \\
\hline $388-97$ & $\begin{array}{l}\text { National Children's Hospital refuses to allow men to take care of } \\
\text { their children. }\end{array}$ & Lost (d) \\
\hline $5732-98$ & $\begin{array}{l}\text { INA (vocational training state agency) has no programs for women, } \\
\text { as indicated by law. }\end{array}$ & Lost (c) \\
\hline $6189-00$ & $\begin{array}{l}\text { CCSS (social security agency) laboratory refused to hire a female } \\
\text { worker. }\end{array}$ & Lost (c) \\
\hline 9196-00 & Discrimination against pregnant women at work. & Lost (c) \\
\hline $11463-00$ & Son was not accepted at school for being from a single-mother. & Lost (c) \\
\hline 7513-01 & $\begin{array}{l}\text { BPDC (Workers' bank) no quota for women on its Board of the } \\
\text { National Assembly }\end{array}$ & Lost (c) \\
\hline $10230-01$ & Job discrimination against women by the Judicial Branch. & Lost (c) \\
\hline
\end{tabular}


Table 3 (continued)

\begin{tabular}{|r|l|c|}
\hline $3150-94$ & Against the 12 hour job for women who work in domestic services. & Lost (c) \\
\hline $2366-99$ & $\begin{array}{l}\text { Representatives of women and of other political forces were } \\
\text { disrespected. }\end{array}$ & Lost (c) \\
\hline $1086-02$ & $\begin{array}{l}\text { TV commercial was stopped from being broadcasted for portraying } \\
\text { demeaning image of women }\end{array}$ & Lost (c) \\
\hline $716-98$ & $\begin{array}{l}\text { Protests the lack of woman to the Board of directors of the ARESEP } \\
\text { (prince controlling agency) }\end{array}$ & Won \\
\hline $3419-01$ & Discrimination against women in elected positions. & Lost (c) \\
\hline
\end{tabular}

Source: Corte Suprema de Justicia-Sala Constitucional. 2004.

Note: This table presents only some of the major cases; it is neither exhaustive nor complete. The creation of such a list is, at the moment, impossible as there more than 114,000 cases that would need to be read and coded.

a. Case's resolution number; the two numerals after the hyphen signify the year of the decision.

b. Won Con lugar (ruled in favor of the action).

c. Lost Sin lugar (ruled against the action).

d. Lost Rechazado por razones de fondo (dismissal on the merits).

e. Lost Rechazado de plano (plain dismissal). 